\title{
VERBAL INDICATORS OF FEAR IN THE RUSSIAN LANGUAGE (ON THE MATERIAL OF ARTISTIC LITERATURE)
}

The article analyses the proposals that describe and express the emotion of fear in Russian language. The verbal model of sentences with lexemes is considered: to be afraid, to be afraid, to panic, to be frightened, to be horrified. The material is selected from Russian fiction. We compare the language constructions that are used in the work of serious fiction (L. Ulitskaya Kazus Kukotsky) and in the popular popular literature (P. Dashkova Blood of the Unborn).

Key words: artistic literature, emotions, fear, verbal, Russian language.

Надійшла до редакиії 16.05.2018 p.

УДК 811.161.2:81'373.611

DOI: https://doi.org/10.18524/2413-0613.2018.22.145397

Н. М. Хрустик,

кандидат філологічних наук,

доцент кафедри української мови філологічного факультету

Одеського національного університету імені І. І. Мечникова, Французький бульвар 24 / 26, м. Одеса, 65058, Україна,

тел.: 0993194217,

kafukrmovaonu@ukr.net

\section{АКТИВНІ ПРОЦЕСИ САОВОТВОРЕННЯ В СУЧАСНІЙ УКРАЇНСЫКІЙ МОВІ: ДИНАМІКА САОВОТВІРНОГО ГНІЗДА З ПРЕФІКСОЇДОМ ВЕИО-}

Стаття присвячена дослідженню активних процесів словотворення в сучасній українській мові. На матеріалі лексикографічних праць розглядається 3'ява та динаміка розвитку словотвірного гнізда 3 префіксоїдом вело-. Приблизно за 150 років функціонування в українській мові досліджуваного словотвірного гнізда у словниках відбито 33 його лексеми. У статті фіксуються також та аналізуються деривати цього словотвірного гнізда, які з'явилися за останні два роки в 3МІ. 3'ясовано, що за цей короткий період часу словотвірне гніздо 3 вершиною вело- поповнилося лексемами втричі. Визначаються й обгрунтовуються причини активного творення його дериватів. Робиться висновок, що висока динаміка розвитку словотвірного гнізда $з$ префіксоїдом вело- $є$ результатом взаємодії мови, зокрема їі словотвірної системи, 3 особливостями розвитку і потребами українського суспільства на сучасному етапі. Лексеми, утворені префіксоїдами, поруч зі складними словами (юкстапозитами, композитами) завдяки особливостям своєї семантикословотвірної структури здатні оперативно й максимально адекватно номінувати всі ті нові явища і процеси, які з'являються. 
Ключові слова: розвиток української мови, ЗМІ, активні процеси словотворення, словотвірне гніздо, складні слова, префіксоїд вело-.

Одна 3 особливостей сучасного українського словотворення - активне реагування на всі зміни в суспільному житті у формі продукування нових слів, які ці зміни називають. Словотвірне гніздо - комплексна багаторівнева одиниця словотвірної системи мови, у розвитку якої відображаються активні сучасні дериваційні процеси.

Мета нашої статті - простежити динаміку розвитку словотвірного гнізда 3 вершиною вело- (велосипед) як приклад відображення активних процесів сучасного українського словотворення. Об'скт вивчення - процес словотворення в сучасній українській мові. Предмет нашого аналізу - розвиток словотвірного гнізда 3 вершиною вело- (велосипед) та активні дериваційні процеси, пов'язані з цим розвитком. Перед собою ставимо завдання: розкрити зміни, які відбулися в системі словотвірного гнізда 3 вершиною вело(велосипед) за останні роки; з'ясувати, з якими дериваційними процесами вони пов'язані; визначити причини цих змін. У дослідженні використано історичний, описовий i функціональний методи, а також елементи морфемного та словотвірного аналізу, кількісні підрахунки.

Питання вивчення тенденцій розвитку мови загалом та іiі окремих підсистем завжди було й нині залишається актуальним. 3 цього погляду особливо показовими є зміни, які відбуваються в системі словотворення, зокрема інноваційні словотвірні процеси, які найбільш чутливі до всіх потреб і викликів суспільства. Вивченню означеної проблематики в українській мовознавчій науці присвячено чимало праць, серед яких найбільш вагомі дослідження Н. Ф. Клименко [5], С. А. Карпіловської [5], Л. П. Кислюк [4; 5], К. Г. Городенської [2], О. А. Стишова [10].

Наше дослідження базується на спостереженнях, які стосуються, головним чином, мови ЗМI, зокрема мовлення Першого каналу українського радіо. У ЗМІ виробляються мовні стандарти, формуються певні мовні смаки у слухачів, стимулюється на цій основі їх власна словотворчість. Усе зазначене робить мас-медіа важливим джерелом з погляду дослідження мовних процесів $[13$, c. 126$]$.

Яскравим прикладом активності словотвірних процесів, які відбуваються в сучасній українській мові, є динаміка словотвірного гнізда з вершиною вело(велосипед). Вело... [< лат. vēlox (velōcis) - швидкий]. Перша складова частина слів, відповідна за значенням слову „велосипедний”, наприклад, велоспорт. Велосипед [< фр. velocipede від лат. vēlox (velōcis) - швидкий + pēs (pedis) нога]. Машина, яку рухає людина за допомогою ножних педалей і ланцюгової передачі [6, с. 96]. Етимологічний словник української мови засвідчує: велосипед, велосипедний - запозичено з французької мови, можливо, через pociйську; фр. velocipede (букв. швидкими ногами) було утворене у Франції на початку XIX ст. $з$ лат. vēlox, velōcis „швидкий”, похідного від veho „везу, їду” і pess, pedis „нога”, спорідненого з дн.-інд. pad „нога” [3, с. 347]. Г. П. Циганенко відзначає, що запозичення слова велосипед із французької мови відбулося в другій половині XIX ст. [14, с. 53]. 
У різних лексикографічних працях із часу запозичення слова велосипед, 3 морфемним складом якого був успадкований також префіксоїд вело-, зафіксовано 33 слова, які мають цей структурний компонент.

В „Українсько-російському словнику” в 6 т. (1953-1963) подається словотвірне гніздо з вершиною вело-, яке складається 38 лексем: велодром, веломашина, велоперегони, велосипед, велосипедист, велосипедистка, велосипедний, мотовелоспорт [12]. Два слова із перелічених (велосипед, велодром) з'явилися в українській мові як запозичення, решта (веломашина, велоперегони, велосипедист, велосипедистка, велосипедний, мотовелоспорт) належать до похідних утворень. Обмежену кількість слів з префіксоїдом вело- у названому словнику, очевидно, можна пояснити тим, що на початку 50-х років минулого століття в радянському суспільстві велосипед як вид транспорту лише почав з'являтися.

В „Етимологічному словнику української мови” Ярослава Б. Рудницького (1962-1972) фіксується словотвірне гніздо з вершиною вело-, яке складається 3 5 лексем: велодром, велосипед, велосипедний, велосипедник, велосипедниця [8]. Цікаво, що лише в цьому словнику, який було видано в Канаді, іменник на позначення особи, яка їде на велосипеді, подається як утворення зі слов'янським суфіксом -ник - велосипедник, а не велосипедист (з латинським суфіксом -ист), як це відображено в усіх інших лексикографічних працях. Від слова велосипедник також за допомогою суфікса слов'янського походження -иц$я$ твориться слово велосипедниия - похідна лексема на позначення особи жін. статі, якій у словниках протиставляється дериват велосипедистка.

„Словник української мови” в 11 т. (1970-1980) подає 12 слів 3 компонентом вело-: велогонка, велогонки, велогонщик, велодром, веломашина, велоперегони, велопробіг, велосипед, зменш. велосипедик, велосипедист, велосипедистка, велосипедний [9]. 3 них - лише 5 нових утворень: велогонка, велогонки, велогонщик, велопробіг, велосипедик.

„Великий тлумачний словник сучасної української мови” (уклад. і голов. ред. В. Т. Бусел) (2004) фіксує 19 слів з префіксоїдом вело-: велобаза, велогонка, велогонщик, велодром, велоергометр, веломашина, веломобіль, велоперегони, велопробіг, велорикша, велосипед, зменш. велосипедик, велосипедист, велосипедистка, велосипедний, велотраса, велотрек, велотур, велотурист [1]. 3'являється 8 нових лексем: велобаза, велоергометр, веломобіль, велорикша, велотраса, велотрек, велотур, велотурист.

Словотвірне гніздо 3 вершиною вело- поповнюється в сучасній українській мові ще 10 новими словами (велобол, велозавод, велокамера, велокоманда, велокрос, веломотогонки, веломотоспорт, велоспорт, велостаниія, велофігурист), які подаються у словниках $[6 ; 11]$.

Отже, наразі у лексикографічних працях зафіксовано 33 лексеми, які мають компонент вело-. Деякі з них відрізняються лише структурно, маючи одне й те ж саме значення (пор.: велосипедист і волосипедник, велосипедистка і велосипедниия, мотовелоспорт і веломотоспорт). Значення більшості слів, зафіксованих у словниках, пов'язане 3 велосипедним спортом. Усе вищезазначене свідчить про низьку динаміку розвитку словотвірного гнізда 3 
префіксоїдом вело-, адже йдеться, очевидно, про приблизно 150 років його функціонування в українській мові. Опираючись на інформацію наведених вище словників, можемо виснувати, що в ті часи, коли аналізоване словотвірне гніздо поповнювалося новими словами (1950-2000рp.), за десятиліття з'являлося і фіксувалося в лексикографічних працях у середньому 3-4 слова. Звичайно, не всі деривати, які утворювалися в зазначений період, були внесені до словників. Пор., наприклад, розм. велик, яке не фіксується словниками. Утім, припускаємо, що нових слів було не так багато, адже суспільство не мало особливої потреби в їх творенні. Окрім того, якщо говорити про мову ЗМІ, то вживання кожного слова регламентувалося чіткими цензурними приписами.

У 2017-2018 pр. в ЗМІ нами зафіксовано 67 нових лексем з префіксоїдом вело-: велоактивіст, велоакція, велоасоціація,,,Веловектор” (організація), велогонщиия, велогромада, велодень, велодім, велодоріжка, велодорога, велоекіпіровка, велоекскурсія, велозамки́, велоінфраструктура, велоквест, велоколона, велокомпанія, велоконцепція, велоланцюги, веломагазин, веломайстер, веломайстерня, веломандрівка, веломандрівник, веломережа, веломісто, велоорганізація, велоофічер, велопарад, велопарк, велопарковка, велопатруль, велопатрульний, велоперевіз, велопішохідний, велоподорож, велополічейський, велопохід, велопрогулянка, велопродавець, велопрокат, велопростір, „Велопростір” (компанія), велоралі, велорух, велосезон, велосипедист-новачок, велосипеднотуристичний, велосипед-тандем, велосмуга, велосотка, велоспільнота, велостоянка, велоструктура, велотовари, велотранспорт, велотуризм, велофест, велофініштур, велохелп, велошкола, велошляхи, електровелосипед, мандрівник-велосипедист, найвелосипедніший, ретровелосипед, топвеломіста. Пор., наприклад: Скоро на вулииях Києва з'являться велополіщейські; У деяких містах України в міськраді з'явилася посада велоофіцера, а у Львові - навіть штатна така посада; Серед топвеломіст Украйни - Львів, Франківськ, Тернопіль, Київ, Кременчук, Вінниия i Миколаїв; На велосипедах-тандемах у велопоході взяли участь незрячі; Завтра в иентрі Києва планується велопарад дівчат; По вулииях Нових Санжар рухається велотранспорт, до якого прикріплені спеціальні карети для збору сміття; У місті люди мають більшу можливість придбати гарну велоекіпіровку; У передачі брав участь Сергій Смирнов - власник велокомпанії „Велопростір”; У Львові відкрився муніџипальний велопрокат; В Одесі проїде велоколона Святих Миколаїв.

Аналізовані похідні утворення за своїм змістом відображають, головним чином, світоглядні зміни членів суспільства, які пов'язані з місцем людини в природі, збереженням довкілля, прагненням вести здоровий спосіб життя, що наразі у зв'язку з вибором українцями європейських цінностей дуже актуальні. Цим пояснюється поява лексики, яка номінує поняття, явища, які стосуються популяризації велосипедного транспорту, його інфраструктури, організації та форм велосипедного руху, його учасників, велотуризму, відпочинку тощо.

Отже, за останні два роки свого функціонування словотвірне гніздо 3 вершиною вело- поповнилося втричі. Звичайно, не всі новоутворені лексеми стануть мовним надбанням. Деякі з них із різних причин забудуться і вийдуть зі 
вжитку. Майже всі лексеми словотвірного гнізда 3 вершиною вело- (велосипед) - іменники, бо саме вони виконують функцію називання нових понять, породжених сучасною дійсністю. Лише 4 утворення - слова інших частин мови (прикметники велопішохідний, велосипедний, велосипеднотуристичний, найвелосипедніший).

Серед нових слів, які з'явилися в словотвірному гнізді, деривати різних рівнів похідності, утворені такими способами словотворення, як слово- та основоскладання (велосипед-тандем, велосипедист-новачок, мандрівниквелосипедист, електровелосипед, ретровелосипед, велоколона), складносуфіксальний спосіб (велосипеднотуристичний), префіксальний (найвелосипедніший). Окремі лексеми утворені лексико-семантичним способом шляхом онімізації (,Веловектор”, „Велопростір”).

Матеріал дослідження свідчить про високу словотворчу активність префіксоїда вело-. Його словотвірна парадигма становить 56 дериватів із 67 нових утворень, які поповнили словотвірне гніздо. Усі ці слова - композитоїди (похідні слова, утворені префіксоїдом - кореневою за походженням морфемою, що функціонально зблизилася 3 префіксом). Пор., например: велоактивіст, велоакиія, велоасоиіація, велогромада, велодень, велодім тощо. Оскільки префіксоїдні утворення за своїми семантико-словотвірними ознаками дуже близькі до складних слів, то вони, як і юкстапозити та композити, здатні оперативно й максимально адекватно номінувати всі ті нові явища і процеси, які з'являються. У них поєднуються стислість і семантична насиченість, проявляється економія мовних засобів [7, с. 163]. Стрімке зростання продуктивності творення дериватів з префіксоїдом вело- пов'язане винятково 3 позамовними чинниками. Позамовні чинники вимагають, а внутрішньомовні сприяють утворенню багатьох нових слів. Ріст емпіричної продуктивності при творенні лексем з префіксоїдом вело- забезпечується його високою системною продуктивністю, обумовленою такими важливими чинниками, як наявність великого масиву слів, з якими цей префіксоїд може взаємодіяти; використання високопродуктивних способів словотворення (слово- та основоскладання); незначні формальні обмеження у процесі деривації, які легко знімаються за допомогою морфонологічних змін; відсутність конкурентних альтернативних способів номінації. Отже, за необхідності за допомогою префіксоїда вело- нові слова можуть продукуватися легко й у потрібній кількості.

Важливим чинником динамічного розвитку словотвірного гнізда 3 вершиною вело- послугувала також словотвірна імпровізація - одна 3 найхарактерніших рис сучасного дериваційного процесу. Відсутність цензури, відчуття свободи, зокрема відчуття внутрішньої свободи, яке з'явилося в громадян, зокрема в журналістів, у зв'язку з бурхливими соціальнополітичними змінами в українському суспільстві, матеріалізувалося у процесі словотворчості [13, с. 126].

Узагальнюючи вищевикладені міркування, можна стверджувати, що висока динаміка розвитку словотвірного гнізда 3 префіксоїдом вело- $\epsilon$ результатом відображення взаємодії мови, зокрема іiі словотвірної системи, 3 особливостями розвитку і потребами українського суспільства на сучасному 
етапі. Лексеми, утворені префіксоїдами, поруч зі складними словами (юкстапозитами, композитами) завдяки особливостям своєї семантикословотвірної структури здатні оперативно й максимально адекватно номінувати всі ті нові явища і процеси, які з'являються. Вивчення інших тенденцій розвитку українського словотворення, пов'язаних із потребами у збагаченні мови новими словами, становить перспективу дослідження.

\section{Список використаних джерел та літератури}

1. Великий тлумачний словник сучасної української мови / уклад. і гол. ред. В. Т. Бусел. Київ; Ірпінь : Перун, 2004. 1440 с.

2. Городенська К. Г. Нові явища та процеси в українському словотворенні: динаміка чи диструкція словотвірних норм. Українська мова. 2013. № 2. C. 3-12.

3. Етимологічний словник української мови : у 7 т. / АН УРСР, Ін-т мовознавства імені О. О. Потебні; гол. ред. О. Мельничук. К.: Наук. думка, 1982. T. 1.634 c.

4. Кислюк Л. Вплив авторитетних українских видань на формування сучасного обличчя української літературної мови. Тенденції розвитку української лексики та граматики / за ред. І. Кононенко, I. Митнік, С. Романюк. Варшава; Івано-Франківськ, 2015. Ч. 2. С. 26-37.

5. Клименко Н. Ф., Карпіловська С. А., Кислюк Л. П. Динамічні процеси в сучасному українському лексиконі : монографія. К.: Вид. Дім Дм. Бураго, 2008. $335 \mathrm{c}$. $768 \mathrm{c}$.

6. Нечволод Л. І. Сучасний словник іншомовних слів. Харків, 2008.

7. Потиха 3. А. Современное русское словообразование: пособ. для учит. М.: Просвещение, 1970. 384 с.

8. Рудницький Ярослав Б. Етимологічний словник української мови : у 4 т. An etymological dictionary of the Ukrainian language. Вінніпег : УВАК, 1962. Т. 1. Вип. 1-11.968 c.

9. Словник української мови : у 11 т. К.: Наук. думка, 1970-1980. T. $1-11$.

10. Стишов О. Глобалізаційні вияви в словотворенні української i російської мови кінця XX - початку XXI ст. Вісник Прикарп. наи. ун-ту імені В. Стефаника. Філологія. Івано-Франківськ, 2007. Вип. XV - XVIII. С. 204-208.

11. Український орфографічний словник / за ред. А. О. Свашенко. Харків, 1997. $845 \mathrm{c}$.

12. Українсько-російський словник : у 6 т. К.: АН УРСР, 1953-1963. T. $1-6$.

13. Хрустик Н. М. Активні процеси словотворення в сучасній українській мові : складні слова. Слов'янський збірник. Чернівці, 2016. Вип. 20. С. 123-125.

14. Цыганенко Г. П. Этимологический словарь русского языка. 2-е изд., перераб. и доп. К.: Рад. шк., 1989. 511 с. 


\section{Referenses}

1. Velykyy tlumachnyy slovnyk suchasnoyi ukrayins'koyi movy, uklad. i hol. red. V. T. Busel. Kyyiv; Irpin', 2004. 1440 p.

2. Horodens'ka K. H. Novi javyshcha ta protsesy $\mathrm{v}$ ukrains'komu slovotvorenni: dynamika chy destruktsiya slovotvirnykh norm. Ukrayins'ka mova. 2013. № 2, pp. 3-12.

3. Etymolohichnyy slovnyk ukrayins'koyi movy: u 7 t. K., 1982. T. 1. 634 p.

4. Kyslyuk L. Vplyv avtorytetnykh ukrayins'kykh vydan na formuvannya suchasnoho oblychchya ukrayins'koyi literaturnoyi movy. Tendentsiyi rozvytku ukrains'koyi leksyky ta hramatyky. Varshava; Ivano-Frankivs'k, 2015. Ch. 2, pp. 2637.

5. Klymenko N. F., Karpilovska Ye. A., Kyslyuk L. P. Dynamichni protsesy v suchasnomu ukrayins'komu leksykoni: monohrafiya. K., 2008. 335 p.

6. Nechvolod L. I. Suchasnyi slovnyk inshomovnykh sliv. Kharkiv, 2008. 768 p.

7. Potikha Z. A. Sovremennoe russkoe slovoobrazovanie. M., 1970. 384 p.

8. Rudnyckyi Jaroslav B. An etymological dictionary of the Ukrainian language: in 4 Vol. Vinnipeg, 1962. Vol. 1, parts 1-11. 968 p.

9. Slovnyk ukrayinskoyi movy : u 11 t. K., 1970-1980. T. 1-11.

10. Styshov O. Hlobalizatsiyni vyyavy v slovotvorenni ukrains'koyi i rosiys'koyi movy kintsya XX - pochatku XXI st. Visnyk Prykarp. nats. in-tu imeni V. Stefanyka. Filolohiya. Ivano-Frankivs'k, 2007. Vyp. XV-XVIII, pp. 204-208.

11. Ukrains'kyi orphohraphichnyi slovnyk za red. A. O. Svashenko. Kharkiv, 1997. 845 p.

12. Ukrayinsko-rosiyskyy slovnyk: u 6 t. K., 1953-1963. T. 1-6.

13. Khrustyk N. M. Aktyvni protsesy slovotvorennya v suchasniy ukrayins'kiy movi: skladni slova. Slovyans'kyy zbirnyk. Chernivtsi, 2016. № 20, pp. 123-135.

14. Tsyhanenko H. P. Etimologycheskiy slovar' russkogo jazyka. K., 1989. $511 \mathrm{p}$.

\section{Н. М. Хрустык}

\section{АКТИВНЫЕ ПРОЦЕССЫ САОВООБРАЗОВАНИЯ В СОВРЕМЕННОМ УКРАИНСКОМ ЯЗЫКЕ: ДИНАМИКА САОВООБРАЗОВАТЕАЬНОГО ГНЕЗДА С ПРЕФИКСОИДОМ ВЕАО-}

Статья посвящена исследованию активных процессов словообразования в современном украинском языке. На материале лексикографических трудов рассматривается возникновение и динамика развития словообразовательного гнезда с префиксоидом вело-. Приблизительно за 150 лет функционирования в украинском языке исследуемого словообразовательного гнезда в словарях отражены 33 его лексемы. В статье также фиксируются и анализируются дериваты этого словообразовательного гнезда, появившиеся в последние два года в СМИ. Установлено, что за краткий период времени 
словообразовательное гнездо с вершиной вело- активно пополнилось новыми лексемами, увеличившись в три раза. Определяются и изучаются причины активного образования его дериватов. Делается вывод, что высокая динамика развития словообразовательного гнезда с префиксоидом вело- является результатом взаимодействия языка, в частности его словообразовательной системы, с особенностями развития и потребностями украинского общества на современном этапе. Лексемы, образованные префиксоидами, наряду со сложными словами (юкстапозитами, композитами), имея особую семантикословообразовательную структуру, способны оперативно и максимально адекватно называть все те новые явления и процессы, которые возникают.

Ключевые слова: развитие украинского языка, СМИ, активные процессы словообразования, словообразовательное гнездо, сложные слова, префиксоид вело-.

\author{
N. M. Khrustyk, \\ Candidate of Philology, \\ Associate Professor of Ukrainian Language Department \\ Odesa I. I. Mechnikov National University, \\ 24 / 26, Frantsuzky Blvd., Odesa, 65058, Ukraine, \\ tel.: 0993194217 , \\ kafukrmovaonu@ukr.net
}

\title{
DYNAMICS OF THE FAMILY OF WORDS WITH THE PREFIXOID BE 1 - AS AN EXAMPLE OF AN ACTIVE MODERN TREND DEVELOPMENT OF THE UKRAINIAN LANGUAGE IN DERIVATION
}

\section{Summary}

The article is devoted of the question of studying dynamics of the family of words with the prefixoid вело- as an example of an active modern trend development of the Ukrainian language in derivation. The author proves of this problem being adequate, actual and perspective. The active modern trend development of the Ukrainian language in derivation. of different years outlined and defineed in works by N. F. Klymenko, Ye. A. Karpilovska, L. P. Kyslyuk, K. H. Horodenska, O. A. Styshov and other.

The purpose of our research is to study dynamics of the family of words with the prefixoid вело- as an example of an active modern trend of the Ukrainian language in derivation. The object of the research is proper functioning derivation of the Ukrainian language. The subject of our research is dynamics of the family of words with the prefixoid вело- as an example of an active modern trend development of the Ukrainian language in derivation. To teach the aim we should solve such problems: outline the derivative words with the prefixoid вело- in dictionaries of different years and in modern mass media; to study characteristic of the development of the family of words with the prefixoid вело- and what causes its formation. Metodology. The historical, functional, descriptive methods, the method of 
quantitative calculations, the method of morphemic and derivational analysis are used. Findling. The research results show, that the dynamics of the family of words with the prefixoid вело- in modern Ukrainian language is the most high..The important cause of its activity is the necessity of the briefly express an opinion. Practical value. The metodology of studying dynamics of the family of words with the prefixoid вело- as an example of an active modern trend development of the Ukrainian language in derivation can be used in the process of writting textbooks in morphemics and word-formation of the Ukrainian language at a high school. Results. The word-buiding of new derivative words of the family of words with the prefixoid вело- depend of the development of society.

Key words: functioning of the Ukrainian language, mass media, an active trends development in derivation, family of words, complex words, prefixoid вело-.

Надійшла до редакиії 27.06.2018 p. 